\title{
Determinants of Fresh Marine Fish Price Fluctuations, 2000-2019 in South Sulawesi, Indonesia: A Qualitative Independent Variable Estimation Method
}

\author{
Abd. Rahim ${ }^{1, *}$, Diah Retno Dwi Hastuti², Alimudin Laapo ${ }^{3}$ \\ ${ }^{1}$ Department of Economic, Universitas Negeri Makassa, Makassar, Indonesia \\ ${ }^{2}$ Department of Economic, Universitas Negeri Makassa, Makassar, Indonesia \\ ${ }^{3}$ Department of Agricultural Socio-economics, Universitas Tadulako, Palu, Indonesia \\ ${ }^{*}$ Corresponding author.Email: abd.rahim@unm.ac.id
}

\begin{abstract}
Changes in seasons cause an imbalance between supply and demand for fresh marine fish in South Sulawesi, Indonesia. On the supply side, there is oversupply during the fishing season (harvest), while the lean season (west and east) or the fishing season during the total moon production decreases. This also causes fluctuations in fish prices so that the impact on fishermen's income decreases. This study aims to estimate the real fluctuations in the price of fresh marine fish with a regression estimation model of qualitative independent variables. Based on the time dimension using time-series data (2000-2019) sourced from secondary data. The selected fish species are sardinella longiceps, malalugis, and indian mackerel. The findings show that the price fluctuations of the same species of fish affect each other. Likewise, time trends and regional (regency) differences significantly affect fluctuations in the price of fresh marine fish, while per capita income has no significant effect. The support from the government and stockholders in overcoming price fluctuations can be done through increasing catch production by increasing the number of marine fleets with gross tonnage strength and fishing gear with environmentally friendly technology. In addition, it cooperates with the processing industry and obtains price information on both the domestic market and the global market.
\end{abstract}

Keywords: price fluctuations, fresh marine fish, qualitative independent variable

\section{INTRODUCTION}

Fish is one of the world's most traded commodities, and almost $38 \%$ have entered the international market as it contributes significantly to global food security [1]. Furthermore, the reported fact is that global fish and fisheries production is around 154 million tons per year with a consumption level of $18.5 \mathrm{~kg}$ per capita per year [2], mainly marine fish commodities. The capture fisheries sector has an essential role in the local economy and therefore poses a risk to food security at the local [3] and global level in supporting a country's economic growth [4].

Fluctuations in the price of fresh sea fish in South Sulawesi Indonesia have experienced fluctuations in the volume of catch production for 20 years (2000-2019 period) in each district in South Sulawesi (Figure 1). Price fluctuations occur due to seasonal changes (catching and famine) [5], causing an inequilibrium between demand and supply of fresh marine fish [6]. Changes in the price of marine fish depending on supply and demand [7]. On the supply side, during the fishing season, there is oversupply, while the lean season catches production decreases [8]. This also results in price fluctuations so that the impact of fishermen's income decreases [9].

On the demand side of fresh marine fish are the quantity demanded at the price level and income in a certain period. Changes in demand for fresh fish are influenced by fish prices [10], income [11], prices of other products [12], socio-economic fishing practices [11], consumer culture [13], behavioural characteristics and consumption habits [14], as well as demographics and attitudes in making decisions to buy marine fish [15]. On the other hand, the supply of fresh marine fish is influenced by prices and fishing technology, such as ring trawl fishing gear [16] and fishing fleets [17].

Sea fish price fluctuations also occur because they are bought in the middle of the sea and landed in other areas. According to [18], aspects of the marine fish market, such as small pelagic fish, are specifically related to supply 
and demand as price formation. High price fluctuations also provide an opportunity for traders to manipulate price information at the fisherman level in South Sulawesi. According to [8], price fluctuations are asymmetric, meaning that if there is an increase in prices at the consumer level, then the price increase cannot be passed on to producers quickly and vice versa. Although fluctuations often occur, the fishing business sector is very prospective, considering the increasing domestic and international markets demand. If it is associated with an inverse demand system, price variation is explained as a function and quantity variation [19].

Research on fish price fluctuations has been widely carried out in various countries, such as market integration and price exogenousness in fish marketing in Nigeria with the Vector Auto-Regressive (VAR) approach in Nigeria [20]; volatility of fish prices on a global scale based on geographic dimensions, production technology, species, and product form in the European Union, Japan, and the United States [21]; factors influencing fish prices in the Northern Surigao Del Sur market, Philippines by identifying fish quality and water pollution [22]; the price of reef fish using the Tui Hedonic model as a market strategy to increase catch value in France [23]. However, these findings have not discussed the relationship between the same species of fresh marine fish and the study of estimates or the factors that influence price fluctuations using a qualitative independent variable regression estimation method approach by comparing regions.

\section{METHOD}

Quantitative research methods with survey methods are used in this study, namely estimating real price fluctuations of fresh marine fish by using qualitative independent variable regression estimation methods. The research data is based on the time dimension, namely time-series data for 2000-2019 from a combination of 3 districts, namely Barru, Jeneponto, and Sinjai, South Sulawesi Province (Figure 1), so that the total observation data is 60 . The selected fresh marine fish species are Sardinella Longiceps, Malalugis, and Indian Mackerel. This type of fish is a small pelagic that the people of South Sulawesi very much favor.

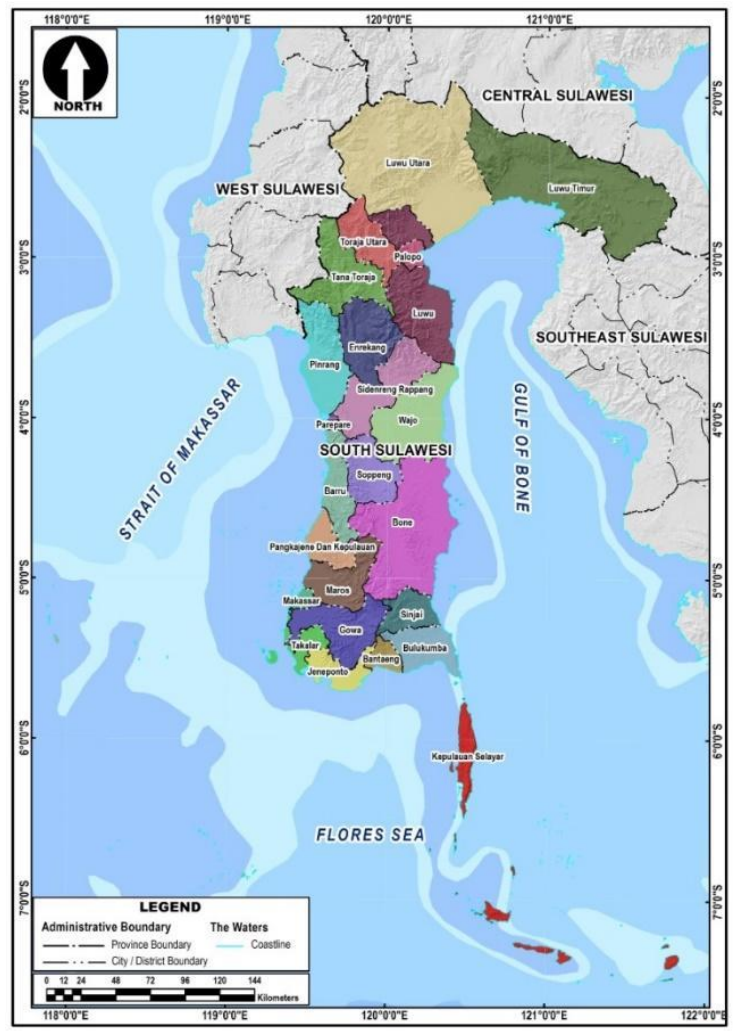

Figure 1 Map of South Sulawesi Province, Indonesia

$$
\begin{aligned}
& \text { PrSrl } g_{t}=\beta_{0}+\beta_{1} P_{r M l_{t}}+\beta_{2} P_{r} I M_{t}+\beta_{3} I P c t+\beta_{4} T m T r_{t}+\delta_{1} D m B D+\delta_{2} D m J D \\
& +\mu_{1 t}
\end{aligned}
$$

$$
P r M l_{t}=\beta_{5}+\beta_{6} P S r L_{g_{t}}+\beta_{7} I M_{t}+\beta_{8} I P c t_{t}+\beta_{9} T m T r_{t}+\delta_{3} D m B D+\delta_{4} D m J D
$$

$$
\begin{aligned}
\operatorname{PrIM}_{t}=\beta_{10}+\beta_{11} \operatorname{PrSrLg}_{t}+\beta_{12} I M_{t}+\beta_{13} I P c t_{t}+\beta_{14} T m T r_{t}+\delta_{5} D m B D \\
+\delta_{6} D m J D+\mu_{3 t}
\end{aligned}
$$

Where : $\operatorname{PrSr} L g$ : sardinela longiceps real price, year $\mathrm{t}$. $\operatorname{PrMl}$ : malalugis real price, year $\mathrm{t}$ PrIM : indian mackerel real price, year $\beta_{0}, \beta_{6}, \beta_{10}$ : intercept. $\beta_{1}, \ldots, \beta_{4 ;} \beta_{6}, \ldots, \beta_{9 ;} \beta_{11}, \ldots, \beta_{14}: \quad$ independent variable regression coefficient. $\delta_{1}, \ldots, \delta_{5}$ : dummy variable coefficient. IPct : income per capita, year t. TmTr: time trend. DmBD : Dummy of Barru Regency. $D m J D$ : Dummy of Jeneponto Regency. Sinjai district is a comparison or control area. $\mu_{1 t}, \mu_{2 t}, \mu_{3 t}$ : disturbance error. $t$ : time series $($ year $=1,2, \ldots, n)$

\section{RESULT AND DISCUSSION}

The measurement of the accuracy of the model using adjusted R2 [24] shows that the independent variables (sardinella longiceps real price, malalugis real price, 
indian mackerel real price, time trend, and dummy regional differences) on fluctuations in the real price of fresh marine fish production can explain as much as $74.2 \%, 84.2 \%$, and $78.7 \%$ of the variations. The F-test hypothesis testing of $29.343,53.235$, and 37.240 showed that the factors that simultaneously influenced the price fluctuations of fresh marine fish in South Sulawesi significantly affected the $1 \%$ error rate. On the other hand, the partial effect based on the t-test hypothesis [24] is that each independent variable on price fluctuations of fresh marine fish in South Sulawesi uses the regression coefficient value (Table 1). The intercept or constant value for the real price fluctuation of fresh marine fish in South Sulawesi is sardinella longiceps -361.338, malalugis -153.041 , and indian mackerel -145.155 . These results indicate that without independent variables (real price of sardinella longiceps, real price of malalugis, real price of Indian mackerel, income per capita, time trend, and regional differences) the intercept/constant value decreased by 361.338, 153.041, and 145.155, respectively.

\subsection{Fresh Marine Fish Price}

The real price of the same species of fresh marine fish influenced each other and was positively influenced between Sardinella longiceps and malaugis at an error rate of $1 \%$ or a confidence level of $99 \%$. This can mean that if the real price of sardinella longiceps rises, the real price of sardinella longiceps will rise, and vice versa if the price of sardinella longiceps rises, then the price of malalugis. A positive influence can occur because apart from the increasing demand for fish consumption, it is due to tastes and preferences in the region. This result is not in line with [22] findings that changes in fish prices are largely determined by the fish quality and water pollution in the Northern Surigao Del Sur, Philippines. On the other hand, Indian Mackerel and Sardinella longicepst, and Malalugis do not influence each other or are affected. This can happen because of changes in tastes from people's requests, so they choose other types of marine fish other than these three types.

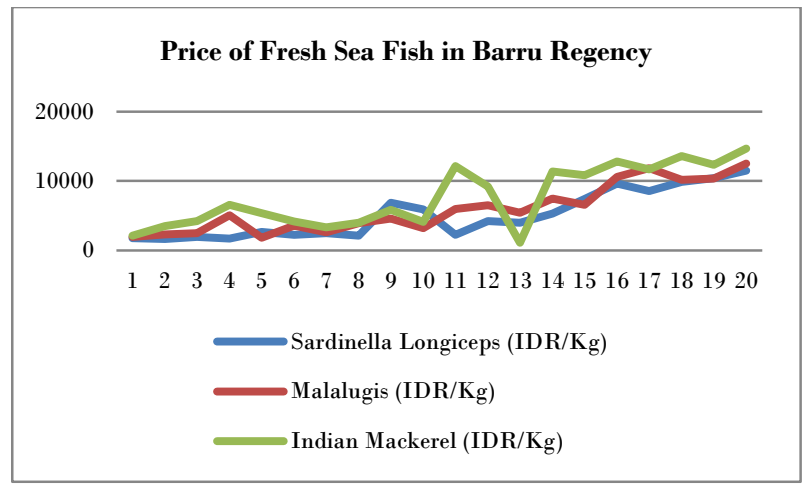

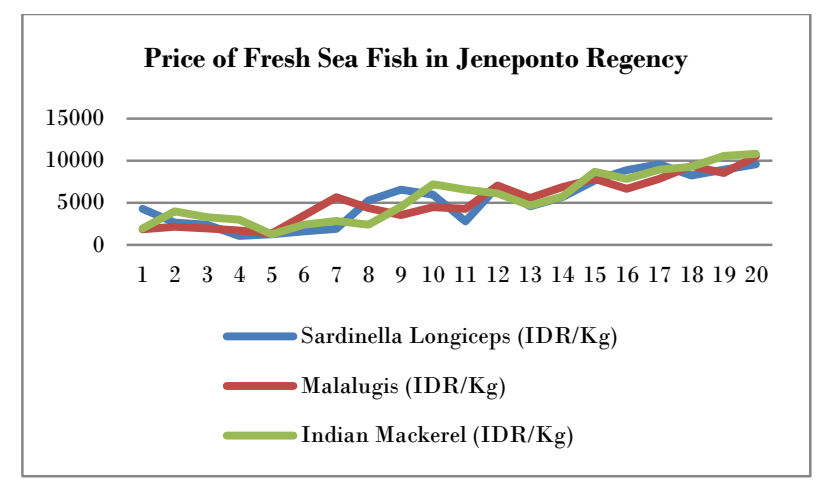

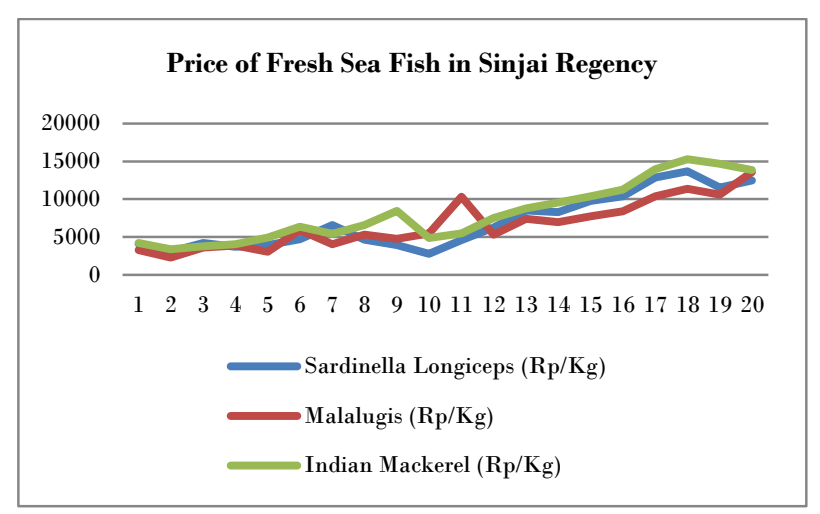

Figure 2 Trends in the Development of Fresh Marine Fish Prices in South Sulawesi (2000-2019)

It shows fluctuations in the price of fresh marine fish in South Sulawesi for the 2000-2019 period occurred in Barru, Jeneponto, and Sinjai Regency, respectively. The highest average price was Indian mackerel at 8,125.64 IDR/kg in Sinjai Regency, followed by Barru and Jeneponto at 7,640.75 IDR/ $\mathrm{kg}$ and 5,588.15 IDR/kg, respectively. The next highest average price is Sardinella longiceps at $6,991.63 \mathrm{IDR} / \mathrm{kg}$ and malalugis $6,670.13$ IDR/kg are also found in Sinjai Regency. On the other hand, the lowest average price for Sardinella Longiceps was found in Barru and Jeneponto Regencies at 5,106.89 IDR/kg and 5,281.35 IDR/kg, respectively (Figure 2).

Any changes (increases and decreases) in production will affect fish price fluctuations in both the producer and consumer markets. Producer markets include fish auction places (FAC) and fish landing centers (FLC), while consumer markets are scattered in various districts, subdistricts, and villages [8]. Fish auctions (producer markets) provide better services to fishers and buyers, while consumer markets receive higher prices, as in eastern Sweden [25]. Changes in supply and demand for fishery products will impact the prices of fish and other substitute products [26]. In line with the findings of [27] in Spain that consumption of marine fish will decline in the future due to changes in consumption habits of other products over the last few years. However, in general, the people of South Sulawesi prefer to consume fish than chicken and beef. The high demand for marine fish products is a center for catch production because it is directly adjacent to the coastal area. This case is the same 
as in urban Lithuania [28]. In addition, the culture of eating fish has long been carried out and has known the benefits of fish meat for body health. According to [29], consumers generally prefer captured fish to be consumed in the catch fish market because of its quality and freshness, while the producer's price is higher than farmed fish.

Table 1. Determinants of Fresh Marine Fish Price Fluctuations in South Sulawesi, Indonesia (2000-2019) using the Qualitative Independent Variable

\begin{tabular}{|c|c|c|c|c|c|c|}
\hline \multirow{2}{*}{$\begin{array}{l}\text { Independent } \\
\text { variable }\end{array}$} & \multicolumn{2}{|c|}{$\operatorname{PrSrLg} g_{t}$} & \multicolumn{2}{|c|}{$\operatorname{PrMl}_{t}$} & \multicolumn{2}{|c|}{$\operatorname{PrIM}_{t}$} \\
\hline & Coef. $(\beta)$ & t-test & Coef. $(\beta)$ & t-test & Coef. $(\beta)$ & t-test \\
\hline$P r S r L g_{t}$ & - & - & $0.132^{* * *}$ & 3.249 & $-0.031^{\text {ns }}$ & -0.653 \\
\hline $\mathrm{PrMl}_{t}$ & $1.262 * * *$ & 3.249 & - & - & $0.132^{\text {ns }}$ & 0.890 \\
\hline $\operatorname{PrIM}_{t}$ & $-0.254^{\mathrm{ns}}$ & -.653 & $0.111^{\mathrm{ns}}$ & 0.890 & - & - \\
\hline IPct & $-1.815^{\text {ns }}$ & -1.014 & $4.391^{\text {ns }}$ & 0.756 & $8.997^{\mathrm{ns}}$ & 1.441 \\
\hline & $8.619^{\text {ns }}$ & 1.632 & $4.001 * *$ & 2.411 & $3.726^{* *}$ & 2.030 \\
\hline$\beta_{4} T_{m T r_{t}}$ & $469.028^{* *}$ & 2.241 & $154.166^{* *}$ & 2.285 & $123.960^{\text {ns }}$ & 1.648 \\
\hline $\begin{array}{c}D m B D \\
D m J D\end{array}$ & \multicolumn{6}{|c|}{ DmJD } \\
\hline Intercept & \multicolumn{2}{|r|}{$-361.338^{* *}$} & \multicolumn{2}{|r|}{$-153.041^{* *}$} & \multicolumn{2}{|r|}{$-145.155^{* *}$} \\
\hline F-test & \multicolumn{2}{|r|}{$29.343^{* * *}$} & \multicolumn{2}{|r|}{$53.235^{* * *}$} & \multicolumn{2}{|r|}{$37.240^{* * *}$} \\
\hline $\begin{array}{l}\text { Adjusted } \\
\mathrm{R}^{2}\end{array}$ & \multicolumn{2}{|r|}{0.742} & \multicolumn{2}{|r|}{0.842} & \multicolumn{2}{|r|}{0.787} \\
\hline $\begin{array}{l}* * * \text { i } \\
* * \text { is } \\
* \text { is } \\
\mathrm{ns} \text { is } \mathrm{n}\end{array}$ & evel err & $\begin{array}{l}\text { significa } \\
\text { significa } \\
\text { ignifican }\end{array}$ & $\begin{array}{l}\text { of } 1 \% \\
\text { of } 5 \% \\
\text { f } 10 \%\end{array}$ & $\begin{array}{l}01 \text { ), or } \\
05) \text {, or } \\
10) \text {, or }\end{array}$ & $\begin{array}{l}\text { dence level } \\
\text { lence level } \\
\text { lence level }\end{array}$ & $\begin{array}{ll}99 & \% . \\
95 & \% . \\
95 & \% .\end{array}$ \\
\hline
\end{tabular}

\subsection{Income Per Capita, Time Trends, and Regional Differences}

$\mathrm{Be}$ sure the symbols in your equation have been defined before the equation appears or immediately following. Please refer to "Equation (1)," not "Eq. (1)" or "equation (1)."

Price fluctuations of fresh marine fish such as sardinella longiceps, malugis, and indian mackerel are not affected by the income per capita of the people of South Sulawesi. This can happen if there is a change in income per capita. People choose other types (besides the three selected fish) even though sardinella longiceps, malalagis, and indian mackerel are cheaper. Taste and preference factors will greatly determine people's choices, besides race, religion, city or village residents, and education [6]. The differences in consumption between regions are caused by people's preferences, which usually vary geographically because not all regions can produce these foodstuffs with the natural conditions of their respective regions [8]. However, fish consumption is a top priority in the research area. Similarly, what happened in Saudi Arabia, consumption and people's preferences prefer fish over chicken and meat for consumption purposes because of their knowledge of the nutritional value of fish [30]. Changes in the income per capita of people in South Sulawesi will affect changes in sea fish price fluctuations and affect their consumption patterns. This case is different from the findings of [13] in Bangladesh that the price and income from fish demand by type are heterogeneous products so that consumption varies according to the type, or it can be said that the estimated elasticity of demand varies between fish species and between income classes. Furthermore, [31] found that the demand for fish in Asia is based on low- and high-income households responding to price and income changes.

The time trend variable has a positive effect on fluctuations in malalugis and indian mackerel price at an error rate of $5 \%$ or a confidence level of $95 \%$, while fluctuations in the price of sardinella longiceps are not influenced by trend variables. Trend variables as timeseries data can be used as independent variables that can overcome the occurrence of autocorrelation [32] in classical assumption testing [24]. In addition, when analyzing linear regression, it is also used to detect longterm trends in the data time series, such as the reliability of the slope of the linear trend [33]. The size of the change in the independent variable depends on the factors that influence it from certain variables in the regression estimation model.

Qualitative independent variables or dummy variables can provide differences in the assumption of constant slope and different intercepts between individuals [24]. In this study, the difference in the district area is used as a qualitative independent variable or a dummy variable on fluctuations in the price of fresh marine fish. The Dummy of Barru Regency has a positive and significant effect at the level of $5 \%$ on price fluctuations of sardinella longiceps and malalugis, respectively, while the price fluctuation of indian mackerel is not affected by the dummy of Barru Regency. Likewise, the Jeneponto Regency dummy had a positive and significant effect on error rates of $10 \%, 5 \%$, and $1 \%$, respectively, on price fluctuations of sardinella longiceps, malalgis, and indian mackerel. The positive effect follows the expected sign, namely the fluctuations in the price of fresh sea fish during the 2000-2019 period in Barru Regency and Jeneponto Regency are more significant than the Sinjai Regency. Empirically, the average price of Sardinella longiceps during the years 2000-2019 in Barru Regency is 5,106.89 IDR/kg smaller than in Jeneponto Regency 5,281.35 IDR/kg and Sinjai $6,991.63 \mathrm{IDR} / \mathrm{kg}$. On the other hand, the price of malalugis 6,670.13 IDR/kg in Sinjai Regency is higher than Barru 5,932.14 IDR/kg and Jeneponto 5,241.82 IDR $/ \mathrm{kg}$. Similarly, the price of Indian mackerel in the Sinjai Regency is $8,125.64 \mathrm{IDR} / \mathrm{kg}$, which is higher than Barru 7,640.75 IDR/kg and Jeneponto 5,588.14 IDR/kg (Figure 2).

\section{CONCLUSION AND SUGGESTION}

The findings show that during the 2000-2019 period, price fluctuations of the same species of fresh marine fish such as Sardinella longiceps, malalugis, and Indian mackerel influenced each other. Likewise, time trends 
and regional differences (Barru, Jeneponto, and Sinjai districts) significantly affect fluctuations in the price of fresh sea fish in South Sulawesi, while per capita income has no significant effect. The support from the government and stockholders in overcoming price fluctuations can be done through increasing catch production by increasing the number of marine fleets with gross tonnage strength to reach fishing grounds and modern fishing gear with environmentally friendly technology. In addition, it cooperates with the captured fish processing industry and provides information on the price of fishery products in both the domestic and global markets.

\section{REFERENCES}

[1] Y. Zhang, Y. Tang, Y. Zhang, Y. Sun, and H. Yang, "Impacts of the COVID-19 pandemic on fish trade and the coping strategies: An initial assessment from China's perspective," Mar. Policy, vol. 133, p. 104748, Nov. 2021, doi: 10.1016/j.marpol.2021.104748.

[2] M. F. Can, A. Günlü, and H. Y. Can, "Fish consumption preferences and factors influencing it," Food Sci. Technol., vol. 35, no. 2, pp. 339-346, Jun. 2015, doi: 10.1590/1678-457X.6624.

[3] A. A. Ibarra, A. S. Vargas, and B. M. Lopez., "Economic impacts of climate change on two Mexican coastal fisheries: implications for food security," J. Econ. Lit. Classif., vol. 36, pp. 1-36, 2012, [Online]. Available: http://www.economicsejournal.org/economics/discussionpapers/2012-64/.

[4] E. Y. Mohammed and Z. B. Uraguchi, "Impacts Of Climate Change On Fisheries: Implications for Food Security In Sub-Saharan Africa," in International Global Food Security, M. A. Hanjra, Ed. Nova Science Publishers, Inc, 2013, pp. 113-145.

[5] A. Rahim, D. R. D. Hastuti, W. Sabar, and Rosmawati, "Comparative Perspective Decisions of Traditional Fisherman by using Outboard Motor and Non-Powered Motor in Choosing Empower Capture Fish Processing Business," in Proceedings of the 1st International Conference on Advanced Multidisciplinary Research (ICAMR 2018), 2019, pp. 550-554, doi: 10.2991/icamr-18.2019.131.

[6] A. Rahim and D. R. . Hastuti, "Demand Estimation of Fresh Sea Fish With Panel Data Model," in International Conference on Education, Science, Art and Tecnology (ICESAT), 2017, no. July, pp. 279287.

[7] A. Moussaoui and P. Auger, "A bioeconomic model of a fishery with saturated catch and variable price: Stabilizing effect of marine reserves on fishery dynamics," Ecol. Complex., vol. 45, p. 100906, Jan. 2021, doi: 10.1016/j.ecocom.2020.100906.

[8] A. Rahim, "Pendekatan Data Panel Metode Common Effect Terhadap Fluktuasi Harga Dinamis Jangka Panjang Ikan Pelagis Kecil (The Panel Data Approaches the Common Effects Method to LongTerm Dynamic Price Fluctuations of Small Pelagic Fish)," JEKPEND J. Ekon. dan Pendidik., vol. 1, no. 1, p. 45, 2018, doi: 10.26858/jekpend.v1i1.5059.

[9] A. Rahim, D. R. D. Hastuti, Firmansyah, W. Sabar, and A. Syam, "The Applied of Cobb-Douglas Production Function with Determinants Estimation of Small-Scale Fishermen's Catches Productions," Int. J. Ocean. Oceanogr., vol. 13, no. 1, pp. 81-85, 2019, [Online]. Available: https://www.ripublication.com/ijoo19/ijoov13n1_0 7.pdf.

[10] F. Virgantari, A. Daryanto, H. Harianto, and S. U. Kuntjoro, "Analisis Permintaan Ikan di Indonesia: Pendekatan Model Quadratic Almost Ideal Demand System (Quaids)," J. Sos. Ekon. Kelaut. dan Perikan., vol. 6, no. 2, p. 191, Jul. 2017, doi: 10.15578/jsekp.v6i2.5772.

[11] J. . Moses, D. . Dwana, D. . Giroh, J. Z, and A. Oluwaseun, "The Influence of Socio-Economic Characteristics on Consumers' Preference on Fish Purchase In Yola North Local Government Area, Adamawa State," Int. J. Environ. Agric. Res., vol. 1, no. 7, pp. 1-11, 2015, [Online]. Available: http://ijoear.com/Paper-November-2015/IJOEARNOV-2015-1.pdf.

[12] R. Kızıloğlu and H. Kızılaslan, "Analysis of factors affecting households' fish consumption in Erzurum, Turkey,” Int. J. Soc. Sci. Educ. Res., vol. 2, no. 2, pp. 419-427, Apr. 2016, doi: 10.24289/ijsser.279055.

[13] M. M. Dey, "Analysis of demand for fish in Bangladesh," Aquac. Econ. Manag., vol. 4, no. 1-2, pp. 63-81, Nov. 2008, doi: $10.1080 / 13657300009380261$.

[14] B. E. Erdogan, S. Mol, and Coşansu, "Factors influencing the consumption of seafood in Istanbul, Turkey," Turkish J. Fish. Aquat. Sci., vol. 11, pp. 631-639, 2011, doi: 10.4194/1303-2712-v11_4_18.

[15] A. F. Ahmed, Z. Mohamed, and M. M. Ismail, "Determinants of Fresh Fish Purchasing Behavior Among Malaysian Consumers," Curr. Res. J. Soc. Sci., vol. 3, no. 2, pp. 126-131, 2011, [Online]. Available:

https://www.researchgate.net/publication/2650457 32_Determinants_of_Fresh_Fish_Purchasing_Beha vior_Among_Malaysian_Consumers. 
[16] G. Hosch, B. Belton, and G. Johnstone, "Catch and Effort Trends in Myanmar's Offshore Fleets Operating Out of Myeik - 2009-2018," Mar. Policy, vol. 123, no. 104298, 2021, doi: https://doi.org/10.1016/j.marpol.2020.104298.

[17] Y. Rousseau, R. A. Watson, J. L. Blanchard, and E. A. Fulton, "Evolution of Global Marine Fishing Fleets and the Response of Fished Resources," Proc. Natl. Sci. United States Am., vol. 116, no. 25, pp. 12238-12243, 2019, doi: https://doi.org/10.1073/pnas.1820344116.

[18] Q. Biscaro and A. Liviero, "A Price Analysis and Management Model for Adriatic Small Pelagic fish (anchovies and pilchards)," New Mediterr. J. Econ., vol. 11, no. 1, pp. 19-26, 2012, [Online]. Available: https://dialnet.unirioja.es/servlet/articulo? codigo $=3$ 897690 .

[19] A. P. Barten and L. J. Bettendorf, "Price formation of fish," Eur. Econ. Rev., vol. 33, no. 8, pp. 15091525, Oct. 1989, doi: 10.1016/00142921(89)90075-5.

[20] T. E. Mafimisebi, "Spatial equilibrium, market integration and price exogeneity in dry fish marketing in Nigeria: A vector auto-regressive (VAR) approach,” J. Econ. Financ. Adm. Sci., vol. 17, no. 33, pp. 31-37, 2012, doi: 10.1016/S20771886(12)70005-7.

[21] R. E. Dahl and A. Oglend, "Fish Price Volatility," Mar. Resour. Econ., vol. 29, no. 4, pp. 305-322, Dec. 2014, doi: 10.1086/678925.

[22] M. P. Alapan, E. L. I. Arpilleda, K. J. R. Altizo, G. K. R. Frias, and J. R. Ravelo, "Factors Affecting the Market Price of Fish in the Northern Part of Surigao Del Sur, Philippines," J. Environ. Ecol., vol. 7, no. 2, pp. 34-41, 2016, doi: 10.5296/jee.v7i2.10469.

[23] A. Nassiri et al., "Hedonic evaluation of coral reef fish prices on a direct sale market," Mar. Policy, vol. 129, p. 104525, Jul. 2021, doi: 10.1016/j.marpol.2021.104525.

[24] D. N. Gujarati and D. C. Porter, Basic Econometrics (5th edition). American: McGraw-Hill, 2009.

[25] C. Hammarlund, J. Blomquist, and S. Waldo, "Local markets and price premiums-The case of the establishment of the Stockholm fish auction," Fish. Res., vol. 236, p. 105853, Apr. 2021, doi: 10.1016/j.fishres.2020.105853.

[26] T. C. Tai, T. Cashion, V. W. Y. Lam, W. Swartz, and U. R. Sumaila, "Ex-vessel Fish Price Database: Disaggregating Prices for Low-Priced Species from Reduction Fisheries," Front. Mar. Sci., vol. 4, Nov. 2017, doi: 10.3389/fmars.2017.00363.
[27] A. Claret et al., "Consumer preferences for sea fish using conjoint analysis: Exploratory study of the importance of country of origin, obtaining method, storage conditions and purchasing price," Food Qual. Prefer., vol. 26, no. 2, pp. 259-266, Dec. 2012, doi: 10.1016/j.foodqual.2012.05.006.

[28] M. Inácio, K. Mikša, M. Kalinauskas, and P. Pereira, "Mapping wild seafood potential, supply, flow and demand in Lithuania," Sci. Total Environ., vol. 718, p. 137356, May 2020, doi: 10.1016/j.scitotenv.2020.137356.

[29] S. Mitra, M. N. Khatun, M. M. H. Prodhan, and M. A. Khan, "Consumer preference, willingness to pay, and market price of capture and culture fish: Do their attributes matter?," Aquaculture, vol. 544, p. 737139, Nov. 2021, doi: 10.1016/j.aquaculture.2021.737139.

[30] A. Khan, F. Aldosari, and S. M. Hussain, "Fish consumption behavior and fish farming attitude in Kingdom of Saudi Arabia (KSA)," J. Saudi Soc. Agric. Sci., vol. 17, no. 2, pp. 195-199, Apr. 2018, doi: 10.1016/j.jssas.2016.04.003.

[31] M. M. Dey et al., "Demand for fish in Asia: a crosscountry analysis*," Aust. J. Agric. Resour. Econ., vol. 52, no. 3, pp. 321-338, Sep. 2008, doi: 10.1111/j.1467-8489.2008.00418.x.

[32] S. Makridakis, S. C. Wheelwright, and V. E. McGee, Forecasting: Methods and Applications (Second Edition), Second. New York: Wiley, 1983.

[33] F. De Leo, A. De Leo, G. Besio, and R. Briganti, "Detection and Quantification of Trends in Time Series of Significant Wave Heights: an Application in The Mediterranean Sea," Ocean Eng., vol. 202, no. 107155, 2020, doi: https://doi.org/10.1016/j.oceaneng.2020.107155. 